Original Research Paper

\title{
Conformal Mapping of Temperature Variation in Compost Heap
}

\author{
${ }^{1}$ Jonah Chukwuemeka Agunwamba and ${ }^{2}$ Oji Achuka Nwoke \\ ${ }^{I}$ Department of Civil Engineering, Faculty of Engineering, University of Nigeria, Nsukka, Enugu State Nigeria, Nigeria \\ ${ }^{2}$ Department of Agricultural and Bioresources Engineering, \\ Faculty of Engineering, University of Nigeria, Nsukka, Enugu State Nigeria, Nigeria
}

\author{
Article history \\ Received: 23-12-2015 \\ Revised: 09-06-2016 \\ Accepted: 17-06-2016 \\ Corresponding Author: \\ Oji Achuka Nwoke \\ Department of Agricultural and \\ Bioresources Engineering, \\ Faculty of Engineering, \\ University of Nigeria, Nsukka, \\ Enugu State Nigeria, Nigeria \\ Email: nwoke.oji@unn.edu.ng
}

\begin{abstract}
Laboratory in vessel trapezoidal compost system was designed and constructed. Temperature variation in the compost heap was measured for five days at various depths. Mathematical model for the variation of temperature of the composting process was developed using Conformal Mapping Technique. One of the parameters in the model had two distinct roots, one a positive root and the other negative root. Prediction of temperature was done using both the positive and negative root. The prediction using positive root was named Predicted 1 while that using negative root was named Predicted 2. Four Polynomial functions were generated and considered as reasonable choice for fitting the Measured Surface Temperature (Ts) and Bottom Temperature (Tb) as a function of the predicted temperature. Predicted 1 showed a polynomial relationship with $T s$ and $T b$. The $R^{2}$ values of these relationships with $T s$ and $T b$ were 0.165 and 0.379 respectively. The $\mathrm{R}^{2}$ value of 0.165 is low and signifies poor estimate of temperature variation in compost heap. On the other hand, the $\mathrm{R}^{2}$ value of 0.379 is adjudged moderately okay for prediction based on previous researchers. Predicted 2 also showed a polynomial relationship with $T s$ and $T b$. The $R^{2}$ values of these relationships with $T s$ and $T b$ were 0.4226 and 0.688 respectively. The $R^{2}$ value of 0.688 is high while 0.4226 is moderate. The $\mathrm{R}^{2}$ values suggested that predicted 2 had a better polynomial relationship with the measured data than predicted 1 . Therefore, can be used as the best fit for the model. In terms of shape characteristics, the model simulated the typical temperature-time profile of previous works on compost temperature models in literature closely. The model like several other studies due to the short time frame precluded presentation of the overall shape of the profile. The T-test result $(p<0.05)$ suggested that the model generally gave accurate estimates of the measured temperature while the standard deviation and coefficient of variability (C.V.\%) Suggested that predicted 2 gave a more accurate estimate than predicted 1 . The results showed also that the decomposition of the compost material used was dominated by the presence of mesophilic bacteria. Further work is suggested to investigate model performance over thermophilic composting time periods, provide further model sensitivity information and incorporate natural ventilation aeration expressions into the model.
\end{abstract}

Keywords: Temperature, Conformal Mapping, Mathematical Model, Compost, Thermophilic, Mesophilic, Psychrophilic

\section{Introduction}

The state variables of primary interest in composting are temperature, moisture content and oxygen concentration. Temperature has been predicted by all models, excepting that of Hamelers (1993). In the model of Haug (1993), temperatures were determined iteratively for a series of discrete steady state heat and 
mass balances, rather than predicted for non-steady state conditions. Models of the effect of temperature on composting reaction rates have been developed from Arrhenius functions (Finger et al., 1976; Haug, 1993; Bari et al., 2000; Neilsen and Berthelsen, 2002), empirically from composting data (Schulze, 1962; Smith and Eilers, 1980; Vander Gheynst et al., 1997; Mohee et al., 1998), empirically from microbial growth data (Kaiser, 1996; Stombaugh and Nokes, 1996) or based on cardinal (minimum, maximum and optimum) temperatures for microbial growth (Rosso et al., 1993).

Experimental composting data has shown that as temperature is increased from about $20^{\circ} \mathrm{C}$, biological activity tends to first increase slowly, then rise moderately to a peak value, following which a rapid decline in activity occurs, typically over a small temperature range. A number of models have generated profiles which reflect this phenomenon well (Haug, 1993; Rosso et al., 1993) or are relatively close to it (Smith and Eilers, 1980).

The temperature of a compost pile is a good indicator of what is happening at the microscopic level. Manure heats up because microorganisms are eating degradable material. These microbes are happiest between $43-66^{\circ} \mathrm{C}$. If the microbes get too hot, too cold, or they run out of nutrients or air, they will stop doing their job. Although composting involves a lot of complex processes, monitoring the temperatures of the piles gives us clues about what is going on. According to Megan et al. (2009), the evidence that something has changed in the pile on a microbial level is a change in temperature. Instead of using an expensive oxygen meter to measure the oxygen levels in the piles, you can guess that the microbes are running out of oxygen as the temperatures decrease. The microbial succession that occurs in composting heaps give rise to an increase in temperature which contributes to the killing of pathogenic microorganisms, plant seeds and insect lavae resulting in a hygienically conditioned product (Hering, 1965; MacGregor et al., 1981). The decomposition of organic wastes or plant residue is accomplished under controlled environmental conditions, which contribute towards optimum microbial activity. The process may be carried out in the open 'windrow' system (Haug, 1993; Bongochgetsakul and Ishida, 2008) or in sophisticated closed reactor (Haug, 1980). Reactors are often aerated, either by vertical or horizontal aeration (Haug, 1993). Reactors can be easily adapted to a laboratory scale and also easily instrumented with sensors and thus are often the subjects of experiments and mathematical modelling (Chandrakanthi et al., 2005; Ekinci et al., 2004; Liang et al., 2004; Lin et al., 2007; Mayo, 1997; Miller, 1989; Petric and Selimbasic, 2008; Sole-Mauri et al., 2007; Stombaugh and Nokes, 1996; Petric et al., 2012; 2015).
Petric et al. (2012) applied the first-order kinetics (based on process variables: Oxygen, temperature, $\mathrm{pH}$, moisture content) in order to simulate the profile of organic matter during the composting process for the mixture of organic fraction of municipal solid waste and poultry manure. Baptista et al. (2010) used simulation model developed by Haug (1993) (with correction factors for temperature, oxygen, moisture and free air space) in order to test the application of the model for the description of the composting process in fullscale mechanical-biological treatment plants.

The global production of chicken manure is estimated to be 457 million tonnes per year (Sekar et al., 2010). This amount is set to increase due to continuous growth of the poultry industry, which is driven by increased demand for cholesterol-free food and chicken- derived products (Magdelaine et al., 2008). Chicken manure contains all identified essential plant nutrients and its fertilizer value is well documented (Kelleher et al., 2002). Soil application of organic amendments, such as chicken manures, is often regarded as the best practicable environmental option for waste disposal (Chambers et al., 2003) and supports the general principles of the waste management hierarchy (DEFRA, 2010).

The expected growth of the global population and the associated increase in demand for food and energy, will increase the reliance on fertilizer inputs (Dawson and Hilton, 2011). The recycling of organic materials would need to increase to: (a) Reduce the reliance on mineral fertilizers, which are going up in price and have, therefore, adverse effects on crop profit margins, (b) ensure that finite resources, such as rock phosphate, are efficiently used and reused and (c) deliver some of the environmental benefits associated with recycling (Dawson and Hilton, 2011; Vitousek et al., 2010; Weikard and Seyhan, 2009). The use of chicken manure as a soil amendment provides an effective means to enhance soil fertility and soil physical conditions (Antonious et al., 2014; Warman, 1986) provided best management practices are followed. The results of a study conducted to determine the efficiency of extraction of soluble nutrients from fresh manures and mature composts by Ksheem et al. (2015) showed that soluble nutrients are more readily extracted from fresh chicken manure.

At present, there is no local inorganic fertilizer manufacturing companies in Nigeria (Adeoti et al., 2014). All the inorganic fertilizers being used in the country are imported from various countries. According to Adeoti et al. (2014), Nigeria consumed 94,400t of in organic nitrogen fertilizers in 2002; 137,603 in 2003; 101,001 in 2004 and 115,041 in 2005; averaging $112,011 \mathrm{t}$ of inorganic nitrogen fertilizer consumed over the period. At the field level, the mean fertilizer use in Nigeria has been estimated at $13 \mathrm{~kg} / \mathrm{ha}$ (Adeoti et al., 2014). However, Gutser et al. (2005) assert that inorganic 
and organic fertilizers differ markedly with regard to their transformation in soils and in the utilization of the applied nutrients by plants. Following the suggestion of Mahmoud et al. (2009) that organic nitrogen from biomanure can be used to replace around $25 \%$ of inorganic nitrogen fertilizer without jeopardizing plant.

The average value of domestic livestock population in Nigeria, is estimated at: Cattle 15,997,567; poultry (chickens) 155,630,670; goats 50,569,783; pigs 6,369,286 and sheep 32,158,042 (Adeoti et al., 2014). The data indicates a high population of chicken in Nigeria similar to other countries of the world (Sekar et al., 2010) and this indicates a high potential for manure production from chicken and other livestocks in Nigeria.

The overall objectives of this study was to model temperature variation in a compost heap and understand the composting process, ultimately to help managers to obtain good quality compost as quickly as possible. The specific objectives of this work were: (i) To design and construct laboratory in-vessel type compost system; (ii) measure temperature variation at different depths in the compost heap (iii) create a model that can be easily used for optimization of composting temperature using conformal mapping approach (iii) Determine the best fit for the model (iv) Compare the result with results from Literature.

\section{Materials and Methods}

\section{Description of Experimental Site}

The experiment was carried out in the Department of Civil Engineering Waste Management laboratory, Faculty of Engineering, University of Nigeria Nsukka (Latitude $06^{\circ} 25^{\prime}$ North; Longitude $07^{\circ} 24^{\prime}$ East and altitude of $447.2 \mathrm{~m}$.

\section{Description of the Compost System}

The compost heap used in the experiment is a laboratory scale in vessel compost system prepared by piling maize straw and poultry manure in open-ended trapezoidal wooden vessel (Fig. 1). The total surface area of the compost system is $4.05 \mathrm{~m}^{2}$. The Maize straw was shredded in order to homogenize them and to enable formation of compact mass during the composting. A compact mass is necessary for development and maintenance of temperature within the heap. After shredding, the homogenous material was mixed with poultry manure or droppings in the ratio of $3: 1$ (maize straw to poultry droppings) which provided the nitrogen source. Water was added to the substrate in a $1: 1, \mathrm{w} / \mathrm{w}$ in order to achieve a moisture content of approximately 50 to $60 \%$ in the initial substrate. This is the optimum level of moisture required to initiate microbial activity in compost heaps. The heap was covered with plastic sheet so as to prevent excessive moisture development in the heap as rainfall is unpredictable in the region where the experiment was carried out. The compost within the vessel was assumed to remain static and was not turned or changed during the simulation. The vessel was passively-aerated, i.e., there is no forced aeration. Instead, a wire-mesh was provided by the vertical sides of the vessel that enabled air to flow through.

Even though the research objectives were specifically on modeling temperature variation in the compost heap, the initial composition of composting materials is also important for better understanding of the system. Hence the initial conditions were: Density $\left(435 \mathrm{~kg} / \mathrm{m}^{3}\right)$, moisture content $(\sim 60 \%), \mathrm{pH}(7.54)$, volatile solid content $(83.7 \%)$, mass ratio (poultry manure: Maize straw was 1:1).

\section{Temperature Measurement}

The temperature of the compost system was measured twice a day using thermocouple at various depths to determine its variation with respect to depth. Temperature measurements were taken along the vertical axis with the top of the heap as the origin (Zero). This therefore implies negative values for the vertical axis down the heap from the top (Fig. 2). The atmospheric temperature $\left(T_{\text {atm }}\right)$ and temperature at the surface of the heap $\left(T_{s}\right)$ was measured along side with temperature at the various depths with temperature at $40 \mathrm{~cm}$ depth serving as the bottom temperature $\left(T_{b}\right)$.

\section{Development of the Model (Fig. 2)}

We shall use the following definition of conformal mapping.

\section{Definition}

The mapping $w=f(z)$ is said to be conformal at point $z_{0}$ if function $f(z)$ is analytic at $z_{0}$ and $f^{\prime}\left(z_{0}\right) \neq 0$ (Agunwamba, 2007). Recall that a function $f(z)$ is called analytic at point $z_{0}$ if it is differentiable at this point. Any complex function $W=f(z)$ serves the purpose of defining the value of $w=u+i v$ for a given value of the argument $z=x+i y$. It may therefore be thought of as a mapping of points of the $z$-plane into the corresponding points in the w-plane. Therefore, using conformal mapping, the empirical equation for predicting the temperature variation determined to be:

$T=\frac{T_{b}-T_{s}}{\pi} \tan \left(\frac{-2.53}{v\left(11+k^{2}\right)^{2}}+\frac{v\left(11+k^{2}\right)^{2}}{10.125}\right)+T_{s}$

Where:

$\mathrm{T}=$ Temperature at a depth in the Heap measured from top or surface

$T_{s}=$ Temperature at the surface of the Heap or at the top of the heap

$T_{b}=$ Temperature at the bottom of the Heap 


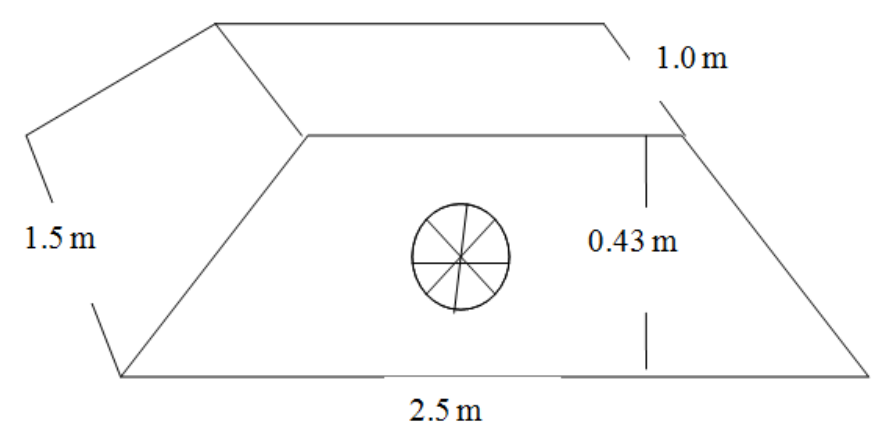

Fig. 1. The wooden trapezoidal shape in-vessel compost system

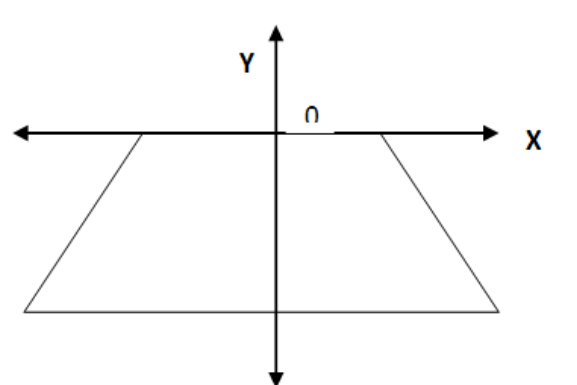

(a)

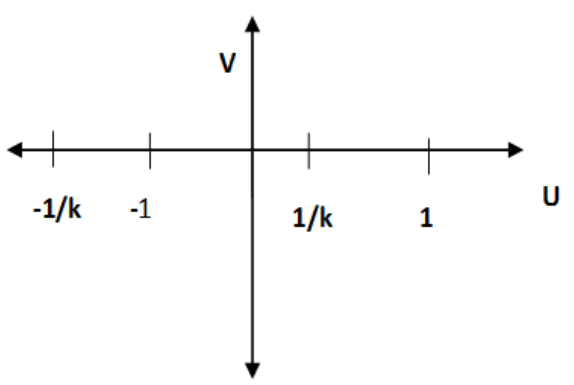

(b)

Fig. 2. The Z and W-plane; (a) Z-plane; (b) W-plane

The parameter $\mathrm{v}$ in equation 1 was determined to be:

$v=\frac{-k_{0} \pm \sqrt{k_{0}^{2}+4 a b y^{2}}}{2 b y}$

In Which:

Where:

$$
\begin{aligned}
& a=\frac{k_{1}}{k_{0}} ; b=\frac{k_{2} k_{0}}{k_{1}^{2}} \\
& k_{0}=\left(11+k^{2}\right) / 0.75 ; k_{1}=9 ; k_{2}=2+k^{2}
\end{aligned}
$$

\section{Determination of Values for $K$ and $V$}

The value for $k$ used in the developed model equation [Equation 26] during prediction was heuristically determined and it has an optimum value of 0.2 . Therefore $k=0.2$ was used throughout the prediction process. The parameter $\mathbf{V}$ according to Equation 2 has positive and negative values. Prediction of Temperature using the developed model (Equation 1) was done using both values of $\mathrm{V}$ and the Predictions were named Predicted 1 and Predicted 2 respectively.

\section{Statistical Analyses}

The results were analyzed using a two tailed T-test $(\mathrm{p}<0.05)$, Differences in Mean, Standard Deviation
(StdDev.), Coefficient of Variability (C.V.\%), Coefficient of Determination $\left(\mathrm{R}^{2}\right)$ and Graphs. Variables more closely related among each other were looked for and the regression model was created so as to subsequently calculate the coefficient of determination or the correlation between variables. However, if the coefficient of determination $\mathrm{R}^{2}$ or the correlation coefficient $\mathrm{R}$ was low (less than 35\%, Mendenhall, 1990), it was determined that the model was too "poor" to make any prediction. All analysis and graphical representation was done using Microsoft Office Excel 2007 Statistical Package.

\section{Results and Discussion}

\section{Values of Parameters Used in the Prediction}

As earlier on explained, the value for $\mathrm{k}$ used in the prediction was heuristically determined to have an optimum value of 0.2 . The values obtained for $k_{1}$, K2, a and $b$ are 9, 2.04, 0.611413 and 0.051378 respectively. The recorded atmospheric temperature during the experiment ranges between $25-30^{\circ} \mathrm{C}$. Vrtually all the predicted temperature $\left(T_{1}\right.$ and $\left.T_{2}\right)$ were observed to be higher than the recorded atmospheric temperature at the time of measurement. The measured Temperature at the surface and bottom ( $T s$ and $T b$ ) of the compost heap were also found to be higher than the recorded atmospheric temperature at the time measurement was 
taken. The surface temperature, Ts was generally found to be lower than the bottom temperature, $T b$. This is an indication that heat was trapped within the mass which insulated naturally by the bulk density of the substrate. This effect is evident in all composting heaps as the process itself is dependent almost entirely on the activity of the indigenous micro-organisms in the substrate which leads to this result.

\section{Result of Temperature-Time Profile}

The result of variation of both measured temperature and predicted temperature with time is as shown in Tables 1-5 and represented graphically in Fig. 3. The result showed that the temperature of the mass composted began to rise or rises extremely slowly after the material was placed in the vessel. Among all microorganisms, aerobic bacteria are the most important initiators of decomposition and temperature increase within the compost pile. Psychrophilic bacteria work in the lowest temperature range and have an optimum temperature lower than $5^{\circ} \mathrm{C}\left(40^{\circ} \mathrm{F}\right)$. It is obvious from Fig. 3 that the temperature was above $20^{\circ} \mathrm{C}$ so the condition of the compost system was not conducive for Psychrophilic bacteria. Mesophilic bacteria do best at temperatures between $10^{\circ}$ and $45^{\circ} \mathrm{C}\left(50^{\circ}\right.$ and $\left.110^{\circ} \mathrm{F}\right)$. Thermophilic bacteria are heat-loving and thrive above $50^{\circ} \mathrm{C}\left(120^{\circ} \mathrm{F}\right)$. Each category includes many strains of bacteria. Figure 3 showed that the decomposition of the compost material was dominated by the presence of mesophilic bacteria as the measured temperature in the system ranged between 29 and $50^{\circ} \mathrm{C}$. While high temperatures have the advantage of killing pathogenic organisms and weed seeds, moderate temperatures encourage the growth of mesophilic bacteria, the most effective decomposers. Since the system temperature was conducive for mesophilic bacteria that were the reason why the composting was achieved within a period of five days. The material composted was not diseased and did not contain seeds; there was no need to be concerned about achieving high temperatures. Decomposers are killed or become inactive if temperatures rise above $60^{\circ} \mathrm{C}$ $\left(140^{\circ} \mathrm{F}\right)$. The rise and fall of temperature during the process as shown in Fig. 3 may be as a result of the material composted, the composting method used and the water available for evaporative cooling. The trend of the graphs in Fig. 3 showed that the predicted 1 over estimated the measured temperature while predicted 2 using showed similar trend with the measured temperature values during the time of composting.

In comparing model performance to experimental data, quantitative measures of performance may be provided by differences in maximum, average and peak temperatures, relative times to reach peak temperatures, the relative areas beneath the curves and a specified baseline and times for which specified temperatures are maintained. Profile shape characteristics may also be compared to typical curves for a qualitative assessment. In the following analysis, parameters used were the mean temperature, standard deviation, coefficient of variation (C.V.\%), two tailed T-test $(p<0.05)$, the times for which thermophilic temperatures were equaled or exceeded $(\mathrm{t} 40)$, the times to reach peak temperatures, the goodness of fit $\left(\mathrm{R}^{2}\right)$ or Coefficient of Determination and the general shape characteristics compared to those of a generic profile. Summaries of the models performance on the above bases are presented in Table 1-5. The temperature-time profile of the model and measured data is presented in Fig. 3. The goodness of fit plots with trend line equations and $\mathrm{R}^{2}$ values are presented in Fig. 4-7. The four Polynomial functions (Equation 1-4) presented in appendix were generated and considered as reasonable choice for fitting the Surface Temperature (Ts) and Bottom Temperature (Ts) as a function of the predicted temperature based on highest $\mathrm{R}^{2}$ value using the developed model.

Considering the polynomial equations (see Appendix), predicted 2 has a stronger polynomial relationship with $T_{S}$ and $T_{B}$ than predicted 1 as shown by their $\mathrm{R}^{2}$ values. Equation 4 has a high $\mathrm{R}^{2}$ value of 0.688 while equation 2 has moderate $\mathrm{R}^{2}$ values of 0.4226 . This shows that Equation 4 can be used to determine temperature variation at the bottom of compost systems to a high degree of accuracy. On the other hand Equation 2 will give a moderate estimate of temperature at the surface. Equation 1 and 3 has low $\mathrm{R}^{2}$ values of 0.165 and 0.379 respectively. The low $\mathrm{R}^{2}$ values signify a poor relationship; therefore equation 1 and 3 if used will give a poor estimate of temperature variation in a compost system. However, Equation 3 can be considered for meaningful prediction of bottom temperature since its $\mathrm{R}^{2}$ value is greater than $35 \%$ (Mendenhall, 1990). Therefore, equation 2 and 4 are considered best fit for the model data.

In terms of shape characteristics, the models (pred.1 and Pred.2) (Fig. 3) simulated the typical profile of the works of Mohee et al. (1998; van Lier et al., 1994; Seki, 2000; Scholwin and Bidlingmaier, 2003) closely, although this was not always well correlated with experimental data (Table 1-5). The model like several other studies (Kishimoto et al., 1987; Nakasaki et al., 1987) due to the short time frame precluded presentation of the overall shape of the profile. The ability of models to predict process temperatures to within a specified margin through to the end of the thermophilic phase and to closely simulate the magnitude and timing of peak temperatures is important if models are to be used to indicate process performance. Whilst acceptable margins are open to debate, it was suggested (Mason, 2006) that maximum, average and peak temperature discrepancies 
of 5,2 and $2^{\circ} \mathrm{C}$, respectively, with peak times predicted to within about $8 \mathrm{~h}$, would be appropriate for the purposes of discussion. Based on these criteria, the model was able to satisfy the conditions for discrepancies in maximum temperature most of the time.
However the conditions for discrepancies in peak temperature and time for peak temperature was rarely met. According to Mason (2006) no models have shown an acceptable predictive ability, although many have met one or more of the goals.

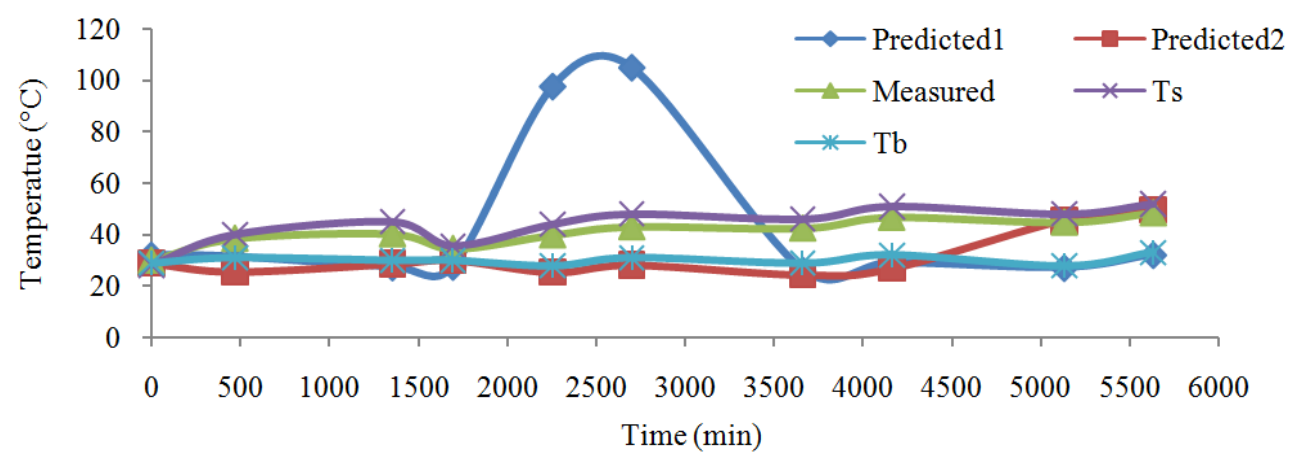

Fig. 3. Temperature-time profile of the compost system

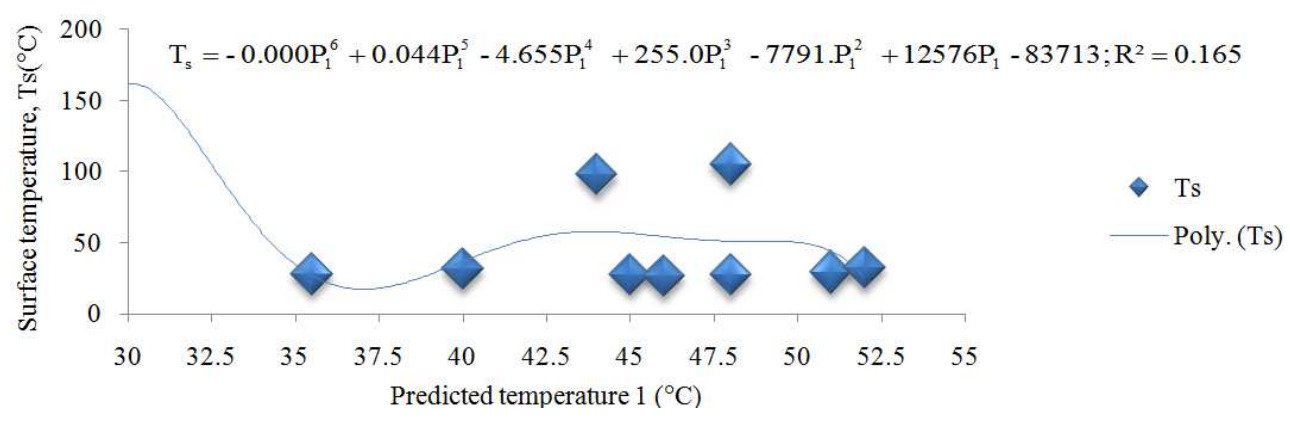

Fig. 4. Plot of surface Temperature (Ts) against mean predicted temperature 1

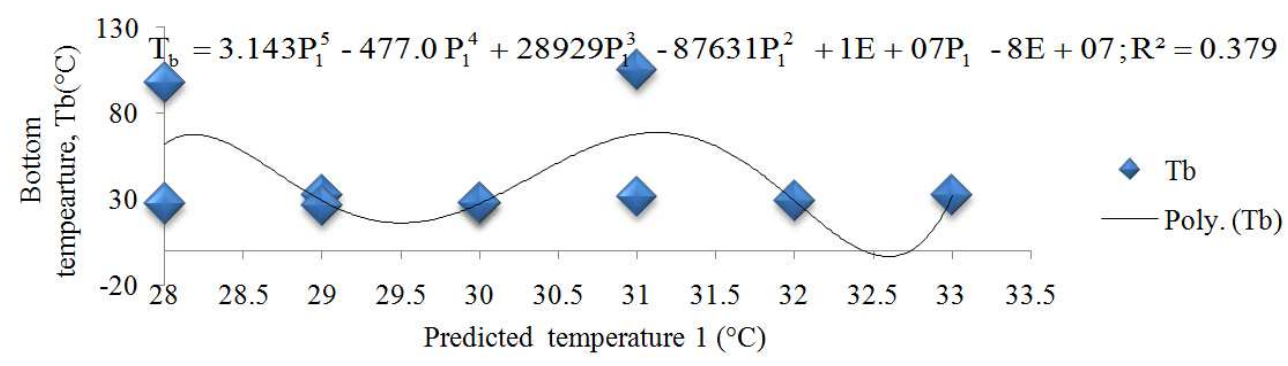

Fig. 5. Plot of bottom temperature $(\mathrm{Tb})$ against mean predicted temperature 1

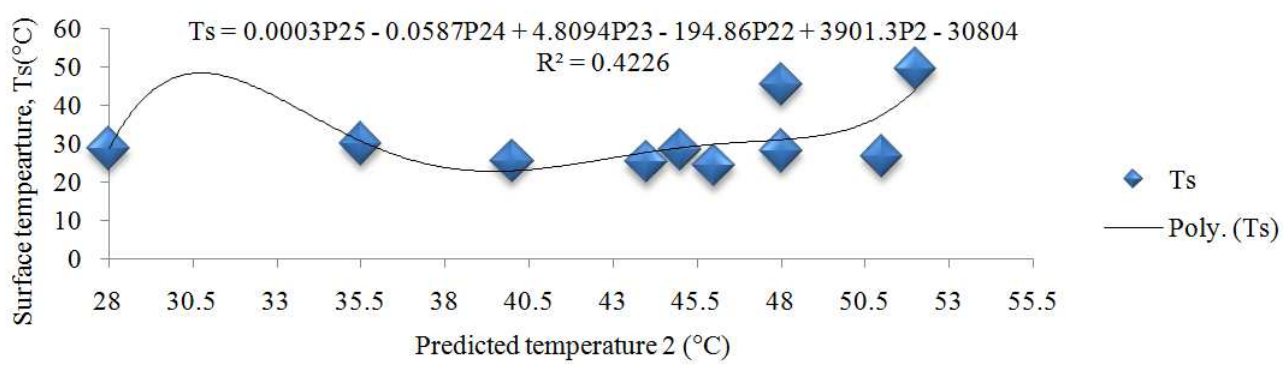

Fig. 6. Plot of surface temperature (Ts) against mean predicted temperature 2 


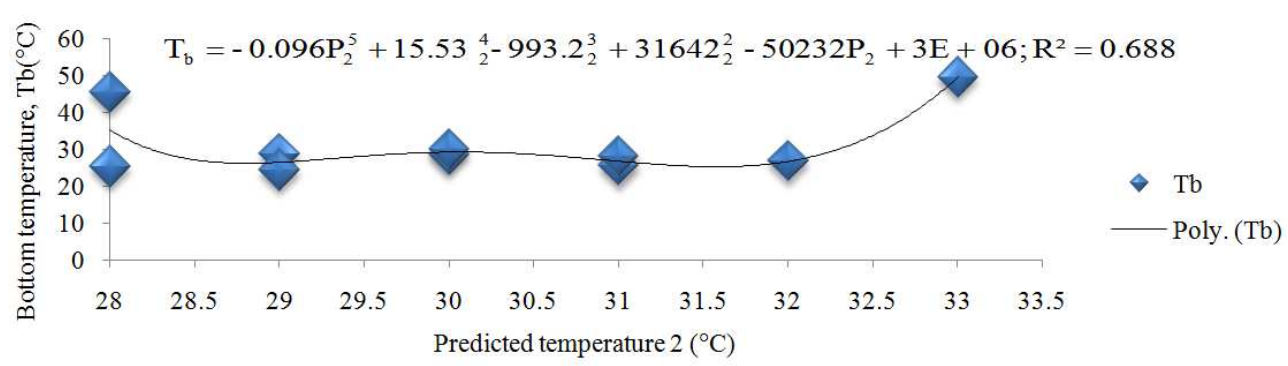

Fig. 7. Plot of bottom temperature $(\mathrm{Tb})$ against mean predicted temperature 2

Table 1. Comparisons of Measured and predicted Temperature from 0-7 h $50 \mathrm{~min}$

\begin{tabular}{llccccc}
\hline & a: 0 h composting & & b: $0-7$ h 50 min of composting & \\
Statistics & Predicted $1\left({ }^{\circ} \mathrm{C}\right)$ & Predicted $2\left({ }^{\circ} \mathrm{C}\right)$ & Measured $\left({ }^{\circ} \mathrm{C}\right)$ & Predicted $1\left({ }^{\circ} \mathrm{C}\right)$ & Predicted 2 $\left({ }^{\circ} \mathrm{C}\right)$ & Measured $\left({ }^{\circ} \mathrm{C}\right)$ \\
\hline Mean & 32.06616510 & 28.761140 & 29.928570 & 31.29386530 & 25.533790 & 38.571430 \\
Stdev & 11.01035820 & 1.766178 & 0.838082 & 4.17560450 & 10.855860 & 2.699206 \\
C.V.\% & 34.33637360 & 6.140848 & 2.800273 & 13.34320470 & 42.515640 & 6.997942 \\
Ttest $(\mathrm{p}<0.05)$ & 0.61782382 & 0.140098 & & 0.00221755 & 0.009474 & \\
\hline
\end{tabular}

Table 2: Comparisons of measured and predicted temperature from $7 \mathrm{~h} 50 \mathrm{~min}-28 \mathrm{~h} 15 \mathrm{~min}$

\begin{tabular}{lllllll}
\hline & a: 7 h 50 min-22 h 35 min composting & b: 22 h 35 min-28 h 15 min of composting \\
Statistics & Predicted $1\left({ }^{\circ} \mathrm{C}\right)$ & Predicted $\left({ }^{\circ} \mathrm{C}\right)$ & Measured $\left({ }^{\circ} \mathrm{C}\right)$ & Predicted $1\left({ }^{\circ} \mathrm{C}\right)$ & Predicted2 $\left({ }^{\circ} \mathrm{C}\right)$ & Measured $\left({ }^{\circ} \mathrm{C}\right)$ \\
\hline Mean & 27.398164 & 28.55994 & 40.33333 & 27.5985226 & 30.02592 & 34.58333 \\
Stdev & 19.4417984 & 7.290908 & 5.609516 & 6.36401122 & 2.02698 & 1.35708 \\
C.V.\% & 70.9602232 & 25.52845 & 13.90789 & 23.059246 & 6.750769 & 3.924087 \\
Ttest $(\mathrm{p}<0.05)$ & 0.14845451 & 0.010601 & & 0.02519165 & 0.001016 & \\
\hline
\end{tabular}

Table 3. Comparisons of measured and predicted temperature from $28 \mathrm{~h} 15 \mathrm{~min}-45 \mathrm{~h}$

\begin{tabular}{|c|c|c|c|c|c|c|}
\hline \multirow[b]{2}{*}{ Statistics } & \multicolumn{3}{|c|}{ a: 28 h 15 min-37 h 35 min composting } & \multicolumn{3}{|c|}{ b: $37 \mathrm{~h} 35 \mathrm{~min}-45 \mathrm{~h}$ of composting } \\
\hline & Predicted $1\left({ }^{\circ} \mathrm{C}\right)$ & Predicted $2\left({ }^{\circ} \mathrm{C}\right)$ & Measured $\left({ }^{\circ} \mathrm{C}\right)$ & Predicted $1\left({ }^{\circ} \mathrm{C}\right)$ & Predicted $2\left({ }^{\circ} \mathrm{C}\right)$ & Measured $\left({ }^{\circ} \mathrm{C}\right)$ \\
\hline Mean & 97.6231925 & 25.29574 & 39.91667 & 104.974642 & 28.12673 & 43.16667 \\
\hline Stdev & 193.817837 & 7.698444 & 4.07942 & 205.931452 & 8.179597 & 5.269409 \\
\hline C.V.\% & 198.536672 & 30.43375 & 10.21984 & 196.172569 & 29.08123 & 12.20712 \\
\hline Ttest $(\mathrm{p}<0.05)$ & 0.48264415 & 0.002108 & & 0.47925329 & 0.003565 & \\
\hline
\end{tabular}

Table 4. Comparisons of measured and predicted temperature from $45-69 \mathrm{~h} 20 \mathrm{~min}$

\begin{tabular}{|c|c|c|c|c|c|c|}
\hline \multirow[b]{2}{*}{ Statistics } & \multicolumn{3}{|c|}{ a: $45-61 \mathrm{~h}$ of composting } & \multicolumn{3}{|c|}{ b: $61-69$ h 20 min of composting } \\
\hline & Predicted $1\left({ }^{\circ} \mathrm{C}\right)$ & Predicted $2\left({ }^{\circ} \mathrm{C}\right)$ & Measured $\left({ }^{\circ} \mathrm{C}\right)$ & Predicted $1\left({ }^{\circ} \mathrm{C}\right)$ & Predicted $2\left({ }^{\circ} \mathrm{C}\right)$ & Measured $\left({ }^{\circ} \mathrm{C}\right)$ \\
\hline Mean & 26.2914311 & 24.34178 & 42.57143 & 28.9727759 & 26.79376 & 46.85714 \\
\hline Stdev & 20.124268 & 11.00004 & 4.237025 & 22.491829 & 12.29417 & 5.45981 \\
\hline C.V.\% & 76.5430682 & 45.18997 & 9.952743 & 77.6309078 & 45.88445 & 11.65203 \\
\hline Ttest $(\mathrm{p}<0.05)$ & 0.0581173 & 0.001495 & & 0.06349658 & 0.001941 & \\
\hline
\end{tabular}

Table 5: Comparisons of measured and predicted temperature from $69 \mathrm{~h} 20 \mathrm{~min}-93 \mathrm{~h} 50 \mathrm{~min}$

\begin{tabular}{|c|c|c|c|c|c|c|}
\hline \multirow[b]{2}{*}{ Statistics } & \multicolumn{3}{|c|}{ a: 69 h 20 min- 85 h 30 min of composting } & \multicolumn{3}{|c|}{ b: 85 h 30 min- 93 h 50 min of composting } \\
\hline & Predicted $1\left({ }^{\circ} \mathrm{C}\right)$ & Predicted $2\left({ }^{\circ} \mathrm{C}\right)$ & Measured $\left({ }^{\circ} \mathrm{C}\right)$ & Predicted $1\left({ }^{\circ} \mathrm{C}\right)$ & Predicedt $2\left({ }^{\circ} \mathrm{C}\right)$ & Measured $\left({ }^{\circ} \mathrm{C}\right)$ \\
\hline Mean & 27.1435352 & 45.49893 & 44.91667 & 32.1863585 & 49.62398 & 48.58333 \\
\hline Stdev & 7.12921324 & 38.35472 & 4.294376 & 6.77275258 & 36.43699 & 5.004165 \\
\hline C.V.\% & 26.2648663 & 84.29808 & 9.560763 & 21.0423077 & 73.42616 & 10.30017 \\
\hline Ttest $(\mathrm{p}<0.05)$ & 0.0003838 & 0.971248 & & 0.00075753 & 0.946111 & \\
\hline
\end{tabular}




\section{Results of Statistical and Graphical Comparisons of Measured and Predicted Temperature}

The discrepancies between the mean temperatures from the beginning to $7 \mathrm{~h} 50 \mathrm{~min}$ of composting were within acceptable limit (Mason, 2006). The model data at this time were in close agreement with the measured data. The standard deviation of these mean temperatures showed that model data predicted 2 were closer to the experimental result at the beginning of composting while model data predict 1 was in a closer agreement after $7 \mathrm{~h}$ $50 \mathrm{~min}$ (Table 1a-1b). The Coefficient of Variability (C.V.\%) of the mean temperatures for predictland Predicted 2 at the beginning of experiment were $34.33 \%$ and $6.14 \%$ respectively. It showed that 2 gave more accurate estimation of the measured temperature. After $7 \mathrm{~h} 50 \mathrm{~min}$, the C.V.\% of Predicted 1 was found to be lower than that of predicted 2, this further confirmed that predict 1 gave a more accurate estimate of the measured temperature as already explained using the standard deviation result (Table $1 \mathrm{~b}$ ). A two tailed T-test at $5 \%$ significant level used to compare the mean temperature of the models data and the experimental data at the beginning of the composting indicated significant differences between the models data and experimental data (Table 1a). However, the results showed that there were no significance differences in the means after $7 \mathrm{~h} 50$ min of composting (Table 1b). Therefore; the models estimated the measured temperature accurately within this period.

Between $7 \mathrm{~h} 50 \mathrm{~min}$ and $22 \mathrm{~h} 35 \mathrm{~min}$ of composting, the standard deviation of the models data showed that predicted 2 gave a more accurate estimate of the measured data than predict1. When compared, the C.V. $\%$ of predicted 2 was found to have a lower value than predict indicating also that predict 2 gave a more accurate estimate of the measured data (Table $2 \mathrm{a}$ ). The T-test result (Table 2a) showed a significant difference between the mean temperatures of predicted 1 and the measured data. However, the T-test result indicated that there was no significant difference between the measured data and predicted 2. The T-test result (Table $2 b$ ) showed that both predicted 1 and predicted 2 gave accurate estimate of the measured data between $22 \mathrm{~h} 35$ min and $28 \mathrm{~h} 15 \mathrm{~min}$ period of composting. Based on the standard deviation and C.V. \% results (Table $2 b$ ), predict 2 gave a more accurate estimate of the measured data than predicted 1 .

Moreover, between $28 \mathrm{~h} 15 \mathrm{~min}$ and $45 \mathrm{~h}$ of composting, the statistical analysis results (Table $3 a-b)$ showed that only predicted 2 estimated the measured data accurately.

From the statistical analysis result presented in Table $4 \mathrm{a}$ for the period of composting between 4 and $61 \mathrm{~h}$, the T-test showed that both predicted 1 and predicted 2 gave accurate estimates of the measured temperature $(p<0.05)$ while the standard deviation and C.V.\% results showed that predicted 2 gave more accurate estimate. However, between 61 and $69 \mathrm{~h} 20 \mathrm{~min}$ of composting, only predicted 2 gave accurate estimate of the measured data $(\mathrm{p}<0.05)$ (Table 4b).

Finally, between 69 h $20 \mathrm{~min}$ and 93 h $50 \mathrm{~min}$ of composting, the results (Table 5a-b) indicated only predicted 1 gave accurate estimate of the measured temperature. From the ongoing discussions, it is clear that the developed model using conformal mapping approach generally gave accurate estimates of the measured temperature at various depths within the compost system used in the experiment for the two scenarios predicted 1 and predicted 2 . However, it is evident from the statistical analysis and graphical representation of the trends that predicted 2 generally gave a more accurate prediction of the measured temperature during the composting period. As explained earlier, predict 2 was computed using the negative values of $\mathrm{v}$ at the w-plane which is a true representation of the measured depth y within the compost system taking zero origin at the surface of the compost heap. That may be the reason why predicted 2, gave a more accurate estimate of the measured temperature.

\section{Conclusion}

Laboratory in Vessel trapezoidal compost system was designed and constructed. Temperature variation in the compost heap was measured for five days at various depths. Mathematical model for the variation of temperature of the composting process were developed. Unlike previously developed models which are based on solution of heat and mass balances, deterministic approach and stochastic approach the model was based on conformal mapping.

The parameter $\mathbf{V}$ in the developed model has two distinct roots, one a positive root and the other negative root. Prediction of Temperature using the developed model was done using both the positive and negative root of $\mathrm{V}$. The prediction using positive root was named predicted 1 while that using negative root was named predicted 2 .

Four Polynomial functions were generated and considered as reasonable choice for fitting the Measured Mean Temperature (M), Surface Temperature (Ts) and Bottom Temperature $(\mathrm{Tb})$ as a function of the predicted temperature, predicted 1 and predicted 2 using the developed model. Predicted 1 showed a polynomial relationship with $\mathrm{Ts}$ and $\mathrm{Tb}$. The $\mathrm{R}^{2}$ values of these relationships with $\mathrm{Ts}$ and $\mathrm{Tb}$ are 0.165 and 0.379 respectively. These $\mathrm{R}^{2}$ values are judged low and indicates a poor estimate of temperature variation in compost heap if used with the model predicted result.

Predicted 2 also showed a polynomial relationship with $T s$ and $T b$. The $R^{2}$ values of these relationships with 
Ts and $\mathrm{Tb}$ are 0.4226 and 0.688 respectively. The $\mathrm{R}^{2}$ value of 0.688 is high while 0.4226 is moderate. This shows that the polynomial function with high $\mathrm{R}^{2}$ value of 0.688 can be used to determine the temperature variation at the bottom of compost heap to a high degree of accuracy. Moreover, the polynomials function with $\mathrm{R}^{2}$ values of 0.4226 and can moderately estimate the surface temperature of a compost heap during composting. Therefore, we conclude that polynomial functions with $\mathrm{R}^{2}$ values of 0.4226 and 0.688 are best fit for the developed model in terms of determining $\mathrm{Ts}$ and $\mathrm{Tb}$.

In terms of shape characteristics, the model (predicted1 and Predicted 2) simulated the typical temperature-time profile of the works of Mohee et al. (1998; van Lier et al., 1994; Seki, 2000; Scholwin and Bidlingmaier, 2003) closely, although this was not always well correlated with experimental data. The model like several other studies (Kishimoto et al., 1987; Nakasaki et al., 1987) due to the short time frame precluded presentation of the overall shape of the profile.

Although the acceptable margins suggested by Mason (2006) for discrepancies in the maximum, average and peak temperature, with peak times predicted to within about $8 \mathrm{~h}$ for predictive ability was not fully met by the model, the statistical analysis suggested that the models predict 1 and predict 2 generally gave accurate estimates of the measured temperature $(\mathrm{p}<0.05)$. Moreover, it further suggested that predicted 2 gave a more accurate estimate than predicted $1(\mathrm{p}<0.05)$.

The result showed that the temperature of the mass composted began to rise or rises extremely slowly after the material was placed in the vessel. The measured surface temperature, $T_{S}$ was generally found to be lower than the measured bottom temperature, $T_{B}$. The results showed that the decomposition of the compost material used was dominated by the presence of mesophilic bacteria as the measured temperature in the system ranged between 29 and $50^{\circ} \mathrm{C}$.

Further work is suggested to investigate model performance over thermophilic composting time periods, provide further model sensitivity information and incorporate natural ventilation aeration expressions into the composting process models using conformal mapping approach. We also suggest a detailed physicochemical analysis of the compost material at each time of temperature measurement.

\section{Funding Information}

The authors have no support or funding to report.

\section{Author's Contributions}

Jonah Chukwuemeka Agunwamba: Contributed in designing the experiment, development of the mathematical model, data analysis, manuscript writing and manuscript reviewing all through the publication process.

Oji Achuka Nwoke: Contributed in performing the experiment, sample analysis, data analysis and manuscript writing all through the publication process.

\section{Ethics}

This manuscript is original and contains not any published material. The corresponding author confirms that all of the others authors have read and approved the manuscript and thus declare no conflicts of interest.

\section{References}

Adeoti, O., T.A. Ayelegun and S.O. Osho, 2014. Nigeria biogas potential from livestock manure and its estimated climate value. Renewable Sustainable Energy Rev., 37: 243-248.

DOI: 10.1016/j.rser.2014.05.005

Agunwamba, J.C., 2007. Engineering Mathematical Analysis: De-adroit Innovation Publishers. 16 Onyiuke street Enugu. Enugu State Nigeria. Enugu, ISBN-13: 978-8137-08-3, pp: 785.

Antonious, G.F., E.T. Turley, R.R. Hill and J.C. Snyder, 2014. Chicken manure enhanced yield and quality of field-grown kale and collard greens. J. Environ. Sci. Health B, 49: 299-304.

DOI: $10.1080 / 03601234.2014 .868681$

Baptista, M., F. Antunes, M. Souteiro Goncalves, B. Morvan and A. Silveira, 2010. Composting kinetics in full-scale mechanical-biological treatment plants. Waste Manage., 30: 1908-1921. DOI: $10.1016 /$ j.wasman.2010.04.027

Bari, Q.H, A. Koenig and T. Guihe, 2000. Kinetic analysis of forced aeration composting-I. Reaction rates and temperature. Waste Manage. Res., 18: 303-312. DOI: 10.1034/j.1399-3070.2000.00114.x

Bongochgetsakul, N. and T. Ishida, 2008. A new analytical approach to optimizing the design of large-scale composting systems. Bioresource Technol., 99: 1630-1641.

DOI: 10.1016/j.biortech.2007.04.016

Chambers, B., F. Nicholson, M. Aitken, E. Cartmell and C. Rowlands, 2003. Benefits of biosolids to soil quality and fertility. J. Chart. Inst. Water E., 17: 162-167. DOI: 10.1111/j.1747-6593.2003.tb00455.x

Chandrakanthi, M., A. Mehrotra and J. Hettiaratchi, 2005. Thermal conductivity of leaf compost used in biofilters: An experimental and theoretical investigation. Environ. Poll., 136: 167-174. DOI: $10.1016 / j$.envpol.2004.09.027

Dawson, C. and J. Hilton, 2011. Fertiliser availability in a resource-limited world: Production and recycling of nitrogen and phosphorus. Food Policy, 36: S14-S22. DOI: 10.1016/j.foodpol.2010.11.012 
DEFRA, 2010. Fertiliser Manual (RB209). TSO Place.

Ekinci, K., H.M. Keener, F.C. Michel and D.L. Elwell, 2004. Modeling composting rate as a function of temperature and initial moisture content. Compost Sci. Utilizat., 12: 356-364.

DOI: $10.1080 / 1065657 X .2004 .10702205$

Finger, S.M., R.T. Hatch and T.M. Regan, 1976. Aerobic microbial growth in semisolid matrices: Heat and mass transfer limitation. Biotechnol. Bioeng., 18: 1193-1218. DOI: 10.1002/bit.260180904

Gutser, R., T. Ebertseder, A. Weber, M. Schrami and U. Schmidhalter, 2005. Short-term and residual availability of nitrogen after long-term application of organic fertilizers on arable land. J. Plant Nutr. Soil Sci., 168: 439-46.

DOI: $10.1002 /$ jpln.200520510

Hamelers, H.V.M., 1993. A Theoretical Model of Composting Kinetics. In: Science and Engineering of Composting: Design, Environmental and Microbial and Utilization Aspects, Hoitink, H.A.J. and H.M. Keener (Eds.), Renaissance Publications, Worthington, USA, pp: 36-58.

Haug, R.T., 1993. The Practical Handbook of Compost Engineering. 1st Edn., CRC Press, ISBN-10: 0873713737, pp: 752.

Haug, R.T., 1980. Compost Engineering: Principles and Practice. 1st Edn., Ann Arbor Science, Michigan, USA, pp: 655.

Hering, T.F., 1965. Succession of fungi in the litter of a lake district Oakwood. Trans. British Mycolo. Society, 48: 391-408.

DOI: $10.1016 / \mathrm{S} 0007-1536(65) 80060-2$

Kaiser, J., 1996. Modelling composting as a microbial ecosystem: A simulation approach. Ecol. Modell., 91: 25-37. DOI: 10.1016/0304-3800(95)00157-3

Kelleher, B., J. Leahy, A. Henihan, T. O'dwyer and D. Sutton et al., 2002. Advances in poultry litter disposal technology-a review. Bioresour. Technol., 83: 27-36. DOI: 10.1016/S0960-8524(01)00133-X

Kishimoto, M., C. Preechaphan, T. Yoshida and H. Taguchi, 1987. Simulation of an aerobic composting of activated sludge using a statistical procedure. MIRCEN J., 3: 113-124.

DOI: $10.1007 / \mathrm{BF} 00933611$

Ksheem, A.M., J.M. Bennett, D.L. Antille and S.R. Raine, 2015. Towards a method for optimized extraction of soluble nutrients from fresh and composted chicken manures. Waste Manage., 45: 76-90.

DOI: 10.1016/j.wasman.2015.02.011

Liang, Y., J. Leonard, J. Feddes and W. McGill, 2004. A simulation model of ammonia volatilization in composting. Trans. ASAE, 47: 1667-1680.

DOI: $10.13031 / 2013.17609$
Lin, Y., G. Huang, H. Lu and L. He, 2007. Modeling of substrate degradation and oxygen consumption in waste composting processes. Waste Manage., 28: 1375-1385. DOI: 10.1016/j.wasman.2007.09.016

MacGregor, S.T., F.C. Miller, K.M. Psarianos and M.S. Finstein, 1981. Composting process control based on interaction between microbial heat output and temperature. Applied Environ. Microbiol., 41: 1321-1330.

Magdelaine, P., M.P. Spiess and E. Valceschini, 2008. Poultry meat consumption trends in Europe. World's Poultry Sci. J., 64: 53-64. DOI: $10.1017 / \mathrm{S} 0043933907001717$

Mahmoud, E., N. Abd El-Kader, P. Robin, N. AkkalCorfini and L. Abd El-Rahman, 2009. Effects of different organic and inorganic fertilizers on cucumber yield and some soil properties. World J. Agric. Sci., 5: 408-14.

Mason, I.G., 2006. Mathematical modelling of the composting process: A review. Waste Manage., 26: 3-21. DOI: 10.1016/j.wasman.2005.01.021

Mayo, A., 1997. Effects of temperature and $\mathrm{pH}$ on the kinetic growth of unialga Chlorella vulgaris cultures containing bacteria. Water Environ. Res., 69: 64-72. DOI: $10.2175 / 106143097 X 125191$

Megan, H., T. Courtney, M. Vicki and B. Sandra, 2009. Compost temperature, compost, compost tea and manuring project funded in 2009. Peace River Agriculture Development Fund. Forage Fact \# 47.

Mendenhall, W., 1990. Statistics for administrators. Grupo Editorial Iberoamericana, S.A. de C.V. México.

Miller, F., 1989. Matric water potential as an ecological determinant in compost, a substrate dense system. Microbial. Ecol., 18: 59-71. PMID: 24196021

Mohee, R., R. White and K. Das, 1998. Simulation model for composting cellulosic (bagasse) substrates. Compost Sci. Utilisat., 6: 82-92. DOI: 10.1080/1065657X.1998.10701923

Nakasaki, K., J. Kato, T. Akiyama and H. Kubota, 1987. A new composting model and assessment of optimum operation for effective drying of composting material. J. Fermentat. Technol., 65: 441-447. DOI: 10.1016/0385-6380(87)90141-5

Neilsen, H. and L. Berthelsen, 2002. A model for temperature dependency of thermophilic composting process rate. Compost Sci. Utilisat., 10: 249-257. DOI: $10.1080 / 1065657 X .2002 .10702087$

Petric, I., E. Avdihodžic and N. Ibric, 2015. Numerical simulation of composting process for mixture of organic fraction of municipal solid waste and poultry manure. Ecol. Eng., 75: 242-249. DOI: 10.1016/j.ecoleng.2014.12.003 
Petric, I., A. Helić and E. Avdihodžić Avdić, 2012. Evolution of process parameters and determination of kinetics for co-composting of organic fraction of municipal solid waste with poultry manure. Bioresour. Technol., 117: 107-116. DOI: $10.1016 /$ j.biortech.2012.04.046

Petric, I. and V. Selimbasic, 2008. Development and validation of mathematical model for aerobic composting process. Chem. Eng. J., 139: 304-317. DOI: $10.1016 /$ j.cej.2007.08.017

Rosso, L., J.R. Lobry and J.P. Flandrois, 1993. An unexpected correlation between cardinal temperatures of microbial growth highlighted by a new model. J. Theoretical Biol., 162: 447-463. DOI: 10.1006/jtbi.1993.1099

Scholwin, F. and W. Bidlingmaier, 2003. Fuzzifying the composting process: A new model based control strategy as a device for achieving a high grade and consistent product quality. Proceedings of the 4th International Conference of ORBIT Association on Biological Processing of Organics: Advances for a Sustainable Society, Apr. 30-May 2, Perth, Australia. ORBIT Association, Weimar, Germany, pp: 739-751.

Schulze, K.L., 1962. Continuous thermophilic composting. Applied Microbiol., 10: 108-122.

Sekar, S., S. Karthikeyan and P. Iyappan, 2010. Trends in patenting and commercial utilisation of poultry farm excreta. World's Poultry Sci. J., 66: 533-571. DOI: $10.1017 / \mathrm{S} 0043933910000607$

Seki, H., 2000. Stochastic modeling of composting processes with batch operation by the Fokker-Planck equation. Trans. ASAE, 43: 169-179. DOI: $10.13031 / 2013.2682$

Smith, R. and R.G. Eilers, 1980. Numerical Simulation of Activated Sludge Composting. EPA-600/2-8C191, USEPA, Cincinnati, OH, USA.

Sole-Mauri, F., J. Illa, A. Magr, F.X. Prenafeta-Bold and X. Flotats, 2007. An integrated biochemical and physical model for the composting process. Bioresource Technol., 98: 3278-3293. DOI: 10.1016/j.biortech.2006.07.012

Stombaugh, D.P., Nokes, S.E., 1996. Development of a biologically based aerobic composting simulation model. Trans. ASAE, 39: 239-250.

DOI: $10.13031 / 2013.27504$

van Lier, J.J.C., J.T. van Ginkel, G. Straatsma, J.P.G. Gerrits and L.J.L.D. van Griensven, 1994. Composting of mushroom substrate in a fermentation tunnel: Compost Parameters and a Mathematical Model. Netherlands J. Agric. Sci., 42: 271-292.

Vander Gheynst, J., L. Walker and J. Parlange, 1997. Energy transport in a high-solids aerobic degradation process: Mathematical modeling and analysis. Biotechnol. Progress, 13: 238-248.

DOI: $10.1021 / b p 970023 q$
Vitousek, P.M., S. Porder, B.Z. Houlton and O.A. Chadwick, 2010. Terrestrial phosphorus limitation: Mechanisms, implications and nitrogenphosphorus interactions. Ecol. Appl., 20: 5-15. DOI: $10.1890 / 08-0127.1$

Warman, P., 1986. The effect of fertilizer, chicken manure and dairy manure on Timothy yield, tissue composition and soil fertility. Agric. Wastes, 18: 289-298. DOI: 10.1016/0141-4607(86)90074-0

Weikard, H.P. and D. Seyhan, 2009. Distribution of phosphorus resources between rich and poor countries: The effect of recycling. Ecol. Econ. 68: 1749-1755. DOI: 10.1016/j.ecolecon.2008.11.006

\section{Appendix: Polynomial Equations}

$$
\begin{aligned}
& T_{s}=-0.000 P_{1}^{6}+0.044 P_{1}^{6}-4.655 P_{1}^{4} \\
& +255.0 P_{1}^{2}+1257 P_{1}-83713 ; R^{2}=0.165 \\
& T_{s}=0.0003 P_{2}^{5}-0.0587 P_{2}^{4}+4.8094 P_{2}^{3} \\
& -194.86 P_{2}^{2}+3901.3 P_{2} R^{2}=0.4226 \\
& T_{b=} 3.143 P_{2}^{5}-477.07 P_{2}^{4}+28929 P_{2}^{3} \\
& -87631 P_{2}^{2}+1 E+07 P_{2}-8 E+07 ; R^{2}=0.379 \\
& T_{b}=0.096 P_{2}^{5}+15.53 P_{2}^{4}-993.2 P_{2}^{3} \\
& +31641 P_{2}^{2}-50232 P_{2}+3 E+06 ; R^{2}=0.688
\end{aligned}
$$

Where:

$M=$ Mean measured temperature

$T_{S}=$ Surface temperature

$T_{B}=$ Bottom temperature

$P_{1}=$ Predicted temperature 1

$P_{2}=$ Predicted temperature 2 